\title{
Mobbing Davranışlarının Amatör Futbolcuların Tükenmişliğine Etkisi*
}

\author{
The Effect of Mobbing Behaviors on Amateur Footballers' Burnout
}

\author{
ORİJİNAL ARAŞTIRMA/ \\ ORIGINAL RESEARCH \\ Bekir S. Y1ldiz ${ }^{1 \dagger}$, \\ Abdurrahman Kepoğlu², \\ Süleyman M. Y1ldız ${ }^{3}$ \\ ${ }^{\mathbf{1}}$ Muğla Gençlik Hizmetleri ve Spor İl \\ Müdürlüğü, \\ http://orcid.org/0000-0003-3652-8985 \\ ${ }^{2}$ Muğla Sitkı Koçman Üniversitesi, Spor \\ Bilimleri Fakültesi, \\ http://orcid.org/0000-0003-0207-9288 \\ ${ }^{3}$ Muğla Sitkı Koçman Üniversitesi, Spor \\ Bilimleri Fakültesi, \\ http://orcid.org/0000-0002-5335-3593
}

\section{$\ddot{O} \mathbf{z}$}

Bu çalışmada, mobbing davranışlarının amatör futbolcuların tükenmişliği üzerine etkisi incelenmiştir. $\mathrm{Bu}$ çerçevede, ilk olarak futbolcuların mobbinge maruz kalma ve tükenmişlik düzeyleri belirlenmiştir. Daha sonra, demografik değişkenler ile mobbingin alt boyutları olan kişi ilişkili mobbing, iş ilişsili mobbing ve fiziksel korkutucu mobbingin futbolcuların duygusal/fiziksel tükenmesi, duyarsızlaşması ve başarıda düşüş hissi üzerine etkisi incelenmiştir. Veri toplama aracı olarak, mobbingi ölçmek için Olumsuz Davranışlar Ölçeği-Futbol, tükenmişliği ölçmek için Sporcu Tükenmişlik Ölçeği kullanılmıştır. Veriler Amatör Futbol Liginde yer alan oyunculardan $(\mathrm{N}=102)$ elde edilmiştir. Verilerin analizinde, betimleyici analiz, güvenirlik, korelasyon ve regresyon analizi kullanılmıştır. Çalışmanın sonucunda amatör futbolcuların mobbing algısının ve tükenmişlik düzeylerinin düşük olduğu ve amatör futbol takımlarındaki mobbing davranışlarının futbolcuların tükenmişliğini anlamlı ve pozitif olarak etkilediği görülmüştür.

Anahtar Kelimeler: Mobbing, Tükenmişlik, Amatör Futbolcu.

\section{Yayın Bilgisi}

Gönderi Tarihi: 16.01 .2018

Kabul Tarihi: 20.12.2018

Online Yayın Tarihi: 31.12 .2018

\begin{abstract}
This study was conducted in order to investigate the effect of mobbing behaviour on the burnout of amateur footballers. The study mainly looked into the exposure level of mobbing behaviors and levels of burnout of footballers and the effects of different dimensions of mobbing, namely as person-related mobbing, work-related mobbing and physically intimidating mobbing, on the emergence of emotional/physical exhaustion and devaluation as well as reduced sense of accomplishment among amateur footballers. To measure mobbing behaviour and burnout, NAQ-F (Negative Acts QuestionnaireFootball) and ABQ (Athlete Burnout Questionnaire) scales were used. Data was gathered from a sample of amateur footballers $(\mathrm{N}=102)$ in the Amateur Football League, in Turkey. Descriptive statistic, reliability, correlation and regression analysis were utilized for the evaluation of data. The study showed that amateur footballers had low levels of mobbing perception and burnout, and mobbing behaviors had a significant and positive effect on amateur footballers' burnout.
\end{abstract}

Key Words: Mobbing, Burnout, Amateur Footballer.

\footnotetext{
* Bu çalışma Muğla Sıtkı Koçman Üniversitesi Sağlık Bilimler Enstitüsü Beden Eğitimi ve Spor Anabilim Dalında Bekir S. Yıldız tarafından hazırlanan "Mobbing Davranışlarının Amatör Futbolcuların Tükenmişliğine Etkisi” isimli yüksek lisans tezinden türetilmiştir.

${ }^{\dagger}$ Sorumlu yazar: Bekir S. YILDIZ, E-Mail: bekir_48_yldz@hotmail.com
} 


\section{GİRIŞ}

Spor sektörü içerisinde futbolun yoğun ilgi görmesi, yaygınlığı, ekonomik ve sosyal hareketliliği futbol üzerine yapılacak araştırmaları zorunlu kılmaktadır. Dolayısıyla seyredenlere daha fazla zevk, heyecan ve sosyal getiri sağlaması, oynayanlara ise daha iyi statü ve ekonomik getiri sağlaması, futbolun sağlıklı şartlarda sürdürülmesine bağlıdır. Futbolun ana aktörleri futbolculardır. Dolayısıyla, futbolcuların iyi bir psikolojik yapıya sahip olması onların performanslarını artıracaktır. Yüksek performans, bir taraftan futbol oyununun kalitesini artırarak seyir zevkine katkı sağlayacak, diğer taraftan futbolculara çeşitli avantajlar sunacaktır. Bu noktada futbolcuların performanslarını düşürecek olgular birer problem olarak karşımıza çıkmaktadır. Mobbing davranışları ve mesleki tükenmişlik olguları da bu problemler içerisinde değerlendirilmektedir (Yıldız, 2015).

Mobbing bir işyerinde çalışanın, diğer bir çalışan veya çalışanlar tarafından kabadayılık yapılarak, hak etmediği ve ahlak dışı davranışlara maruz kalmasını ifade eden bir kavramdır. Mesleki tükenmişlik ise, iş ortamından kaynaklanan çeşitli streslere maruz kalan çalışanın zihinsel, duygusal ve fiziksel olarak tükenmesini ifade eden bir kavramdır. Literatürde, işyerinde mobbing ile mesleki tükenmişlik üzerine yapılmış araştırmalar oldukça yaygındır. Ancak gerek mobbing gerekse mesleki tükenmişlik üzerine futbolcular üzerinde yapılmış araştırmalar ise oldukça kısıtlıdır. Örneğin, İyem (2007) sadece mobbing konusunu profesyonel futbolda incelemiştir. Bu araştırmasında mobbing olgusunun profesyonel futbolda varlığını ortaya koymuştur. Mobbing ve tükenmişlik ilişkisini ele alan araştırmalara göz atıldığında, Yıldız’ın (2015) profesyonel futbolcular üzerinde, Karık ve Yıldız’ın (2015) kadın basketbolcular üzerinde yapmış oldukları araştırmalar dikkat çekmektedir. Her iki araştırma sonuçları mobbing davranışlarının sporcuların tükenmişlikleri üzerinde anlamlı etkileri olduğuna işaret etmektedir.

Futbolda amatör ve profesyonel olarak iki statü bulunmaktadır. Amatör futbol daha çok serbest zamanı kullanmak, haz almak vb. gibi nedenlerle yapılırken, profesyonel futbol para kazanmak amacıyla meslek olarak yapılmaktadır (Amman, 2000:104). Literatürde yapılan araştırmalara göz atıldığında, futbolcularda mobbing ve tükenmişlik ilişkisini inceleyen araştırmaların oldukça sınırlı olduğu görülmektedir. Dünyada ciddi derecede ilgi gören futbol sektöründe bu tür araştırmaların az olması bir problem olarak görülebilir. Çünkü, gerek mobbing davranışlarının gerekse mesleki tükenmişliğin çalışma hayatındaki insanların performansını düşürdüğü ile ilgili ciddi kanıtlar mevcuttur (Devonish, 2013; Demerouti, Bakker ve Leiter, 2014; 
Ekici, 2011). Futbolda oyuncuların performansının olumsuz etkilenmesi, oyuncu ve kulüp açısından hem maddi (parasal) ve manevi (imaj, statü, haz vb.) kayıplara, hem de seyir zevki düşmüş durumlara neden olabilir. Futbolcularda yüksek performansa ulaşmanın yollarından birisinin de onları olumsuz etkileyebilecek durumları mümkün olduğunca ortadan kaldırmaktır. Bu çerçeveden bakıldığında, amatör futbolcular bağlamında mobbingin tükenmişliğe nasıl bir etki edeceğinin ortaya koyması açısından bu çalışma önem taşımaktadır. Dolayısıyla, spor yönetimi alanına katkıda bulunmak amacıyla, bu çalışmada mobbing davranışlarının amatör futbolcuların tükenmişliği üzerine etkisi incelenmiş̧ir.

\section{LITERATÜR BİLGILER}

\section{Mobbing}

Örgüt içinde gerilime ve çatışmalı bir iklime yol açan tüm psikolojik faktörlerin birleşimi sonucunda ortaya çıkan, örgüt sağlığını bozan, çalışanların iş tatminini ve çalışma barışını olumsuz yönde etkileyen temel bir örgütsel sorun olan mobbing, bir işyerinde çalışanların, bir başka kişiyi ya da kişileri rahatsız edici, ahlak dışı ve sistematik söz ve davranışlarla taciz ettikleri; kısaca başkalarına karşı psikolojik şiddet uyguladıkları bir süreçtir. Yaygın amaç, örgütlerde istenmeyen ya da yıpratılmak istenen kişilere karşı baskılar yaparak, onların direnme gücünü yok edip, işten ayrilmalarına neden olmaktır (Tetik, 2010).

Kanun dışı şiddet uygulayan düzensiz kalabalık anlamına gelen mob sözcüğü Latince'de "ortalıkta toplanmak, saldırmak veya rahatsız etmek" anlamına gelmektedir (Davenport, Schwartz ve Elliot, 1999:20). Uluslararası literatür incelendiğinde mobbing kavramı "violence, psychological harassment, psychological terror, bullying" gibi kavramlarla da ifade edilirken, Türkiye'deki araştırmalarda "yıldırma, psikolojik taciz, iş yeri terörü, zorbalık" adları ile ele alınmaktadır.

Literatür incelendiğinde işyerinde mobbing kavramının ilk defa İsveçli Bilim Adamı Heinz Leymann tarafindan ele alındığı görülmektedir. Leymann (1996) yaptığı araştırmalarda iş yaşamında çalşsanların (psikolojik, sosyal ve ekonomik sonuçları olan) bir takım olumsuz davranışlara maruz kaldığını tespit etmiştir. Daha sonraki araştırmalarında mobbing 
davranışlarının aşamaları ve mobbinge maruz kalan çalışanlar üzerindeki psikolojik, sosyal ve ekonomik etkiler üzerinde durmuştur.

Leymann (1996) tanımladığı 45 ayrı mobbing davranışını özelliklerine göre beş grupta sınıflamıştır. Bunlar; kişinin saygınlığına saldırı, performansa yönelik saldırılar, iletişime yönelik saldırılar, sosyal koşullara yönelik saldırılar ve fiziksel saldırı tehdidi. Bu davranışlardan herhangi biri bir defaya mahsus ve sınırlı olmak üzere belli şartlardan dolayı ortaya çıkabilir. Buna mobbing demek doğru olmaz. Mobbing davranışının söz konusu olabilmesi için, daha önce de belirtildiği gibi, hedef gözetilmek suretiyle mobbinge giren birçok davranışın uzun süreli tekrarı gerekmektedir. Mobbing davranışlarını ölçmek amacıyla bir takım araştırmalar yapılmıştır. Leyman'in (1996) 48 maddeli Leymann Inventory of Psychological Terror (LIPT), Neuman ve Keashly'in (2004) 60 maddeli Workplace Aggression Research Questionnaire (WAR-Q) ve Einarsen, Hoel ve Notelaers'in (2009) 22 maddeli Negative Acts Questionnaire-Revised (NAQR) ölçekleri örnek olarak verilebilir.

İşyerinde mobbingin belli bir nedeni yoktur; birçok faktör mobbingin ortaya çıkmasına kaynaklık edebilir. Başlangıçta iki taraf arasında bir anlaşmazlık olur. Hedef şahıs boyun eğmeyi reddettiği, kontrole direnç gösterdiği için öfkelenen ve kabadayılaşan mobber (mobbing uygulayan kişi) harekete geçer. Artık onun için tek amaç, ulaşılacak bir tek hedef vardır; o da kendisini rahatsız eden, tekerine çomak soktuğunu düşündüğü veya kendisinin aslında çıplak olduğunu gören hedefi zayıflatmak, yaptığına pişman edip kendisini yadsır hale getirmek, sonuçta yer değişmesini, mümkünse işten ayrılmasını sağlamaktır. Kurban (mobbinge maruz kalan kişi), yetenekleri ve kişiliği ile öne çıkıyor ise bu durum mobberi rahatsız eder; zira mağdurun yeteneği, mobberin yalan, iftira, göz boyama ve karalama üzerine kurduğu statüsünü sarsar. Bu durumda mobber bastığı dalın kesilmekte olduğu düşüncesiyle ve adeta can havliyle kurbana saldırıya geçer (Tutar, 2015:143). Bu davranışların mağdurlara, mobberlere ve işletmelere bir takım sonuçları bulunmaktadır (Tınaz, 2006). İşyerinde mobbing davranışlarına maruz kalan mağdurlar ekonomik (örneğin, işten ayrılma), sosyal (örneğin, sosyal imajın zedelenmesi), ruhsal ve fiziksel sağlık (örneğin, depresyon) açısından negatif etkilenmektedir. Mobberler ise, davranışları sonucunda hukuksal olarak ciddi yaptırımlarla karşı karşıya kalmaktadırlar. Diğer taraftan, işletmeler yetenekli ve alanında uzmanlaşmış çalışanların işten ayrılması ile iş kalitesi ve genel performans düşüklüğü ile karşı karşıya kalmaktadırlar (Yıldız, 2017). 
Literatürde mobbing konusunu ele alan araştırmalar oldukça yaygındır ve spor alanında da bir takım araştırmalar yapılmıştır. Ancak spor alanında yapılan araştırmalar oldukça kısıtlıdır (Salman ve Yalçındağ, 2017). Bu araştırmalara göre, diğer sektör çalışanlarında görülen mobbing olgusunun varlığı sporcularda da söz konusudur (İyem, 2007; Salman ve Yalçındağ, 2017). Tüm araştırma sonuçları mobbing davranışlarının sporcuların performanslarını olumsuz etkilediğini vurgulamaktadır.

\section{Mesleki Tükenmişlik}

İlk kez iş ilişkili stres olarak ele alan klinik psikolog Herbert J. Freudenberger tükenmişlik kavramını "başarısız olma, yıpranma, enerji ve güç kaybı ya da karşılanamayan görev talepleri sonucu bireyin içsel kaynaklarında tükenme durumu" şeklinde tanımlamıştır (Freudenberger, 1974). Günümüzde en yaygın olan tanım Maslach’a aittir. Maslach (2003) tükenmişliği “işyerinde stresörlerin uzun etkileri ile ortaya çıkan bir psikolojik sendrom" olarak tanımlamıştır.

Tükenmişliği bir süreç olarak ele alan Maslach, duygusal tükenme, duyarsızlaşma ve kişisel başarıda düşüş hissi olarak üç boyutta incelemiştir. Maslach'a göre birbirinden farklı gibi görünen bu üç boyut temelde birbirleri ile ilişkilidir. Tükenmişlik, iş ortamındaki stres kaynaklarına yönelik tepki olarak çalışanda ilk duygusal tükenme ile başlar. Duygusal olarak yıpranan kişi işe ve çevresindekilere (çalışma arkadaşları, müşterilere) karşı duyarsızlaşır. Duyarsızlaşan kişi, çalışma ortamındaki iş gereklerini karşılayamadığı ve yeteneğini tam olarak yansıtamadığı için başarıda düşüş hissine kapılır (Maslach ve Jackson, 1981).

Çalışanların mesleki tükenmişliğini etkileyen faktörler "bireysel ve sosyal faktörler" ile "işs ve çalışma ortamı ile ilgili faktörler" olarak ikiye ayrılabilir. Bireysel özellikler, bireyin sahip olduğu, bazı durumlarda tükenmişliğe zemin hazırlayan ya da tükenmişliği artıran, bazı durumlarda ise tükenmişliği ve etkilerini azaltıcı bir rol oynayan özellikleri ifade etmektedir. Tükenmişliği etkileyen bireysel ve sosyal özellikler arasında cinsiyet, yaş, eğitim, medeni durum, işte çalışma süresi, sosyal destek, kişilik ve beklentiler sayılmaktadır (Arı ve Bal, 2008). Çalışma ortamı ile ilgili faktörler, iş yoğunluğu, rol çatışması ve rol belirsizliği, işi-yükü kontrolü vd. faktörlerden oluşur. İş ortamında yoğun tempo ve stres altında çalışan bireyler tükenmişlikle karşı karşıya kalmaktadırlar. Yoğun gerilim altında çalışma bireylerin verdikleri hizmetin niteliğinde bozulmalara, bu da hem iş hem de aile yaşamını olumsuz etkilemektedir (Ok, 2012). Literatür, 
çalışanların olumsuz etkilenerek performansının düşmemesi için işyerinde mesleki tükenmişliğin azaltılması gerektiğini ileri sürmektedir (Ekici, 2011).

Literatürde mesleki tükenmişlik konusunu ele alan araştırmalar oldukça yaygın olmakla birlikte, spor alanında tükenmişlik konusunu ele alan araştırmalar da mevcuttur. Ancak spor alanında daha çok antrenör tükenmişliğine (Biber, Ersoy, Acet ve Küçük, 2010) odaklanıldığı, buna karşın sporcu tükenmişliği (Kelecek ve Göktürk, 2017) bağlamında araştırmaların oldukça kısıtlı olduğu görülmektedir. Genel olarak araştırmalar tükenmişliğin çalışanların performansı üzerinde negatif etkisini vurgulasa da, sporcu tükenmişliği üzerine yapılacak araştırmaların fazlalaşması, tükenmişlik olgusunun sporcular üzerindeki etkilerinin daha iyi anlaşılmasını sağlayacaktır.

\section{YÖNTEM}

\section{Araştırmanın Modeli}

$\mathrm{Bu}$ çalışma amatör futbol liglerinde mücadele eden futbolcular üzerinde genel tarama modelinden biri olan ilişkisel tarama modeline göre yürütülmüsşür. İlişkisel tarama modelleri, iki ve daha çok sayıdaki değişken arasında birlikte değişim varlığını ve/veya derecesini belirlemeyi amaçlayan araştırma modelleridir (Karasar, 2005:77,81).

\section{Veri Toplama Araçları}

Çalışmada, mobbingi ölçmek için Yıldız (2015) tarafından futbola özgü olarak geliştirilen “Olumsuz Davranışlar Ölçeği-Futbol” kullanılmıştır. Bu ölçek 12 maddeli ve 3 alt boyutludur (kişi ilişkili mobbing, iş ilişkili mobbing, fiziksel korkutucu mobbing). Bu ölçme aracının psikometrik özelliklerine bakıldığında, aracın diğer araştırmalarda kullanılabilmesi için, gerekli ölçütleri karşılamada oldukça yeterli olduğu görülmektedir. Tükenmişliği ölçmek için Raedeke ve Smith (2001) tarafından geliştirilen “Sporcu Tükenmişlik Ölçeği” kullanılmıştır. Bu ölçek 15 maddeli ve 3 alt boyutludur (başarıda düşüş hissi, duygusal/fiziksel tükenme, duyarsızlaşma). Sporcu Tükenmişlik Ölçeği’nin Türkçe'ye uyarlama çalışması Kelecek, Kara, Çetinkalp ve Aşçı (2016) tarafından yapılmıştır. Bu ölçeğin uyarlamasının, orijinal model ve farklı kültür uyarlamaları ile iyi uyum gösterdiği saptanmıştır. Ölçeklerin geçerliliği daha önce yapılan araştırmalarda (Karık 
ve Yıldız, 2015; Yıldız, 2015) test edildiğinden tekrar faktör analizi yapılmasına gerek görülmemiştir.

Her iki ölçek Likert tipi (1=Hiçbir zaman, 2=Nadiren, 3=Ara sıra, 4=Çoğu zaman, 5=Her zaman) beşli dereceden oluşmaktadır. Ölçekler önce Türkçe'ye çevrilerek alan uzmanlarına kontrol ettirilmiştir. Ardından olası anlaşılamayan yerlerin düzeltilmesi amacıyla 5 futbolcuya incelettirilmiştir. Küçük düzeltmeler yapıldıktan sonra ölçekler uygulama formu haline getirilmiştir.

\section{Evren ve Örneklem}

Amatör futbolcular araştırmanın evrenini oluşturmaktadır. Çalışma evreni ise Ege Bölgesidir. Örneklem ise Amatör Liglerde mücadele eden Didim Belediyespor, Bodrumspor, Ortaca Belediyespor, Ödemişspor ve Muğlaspor futbolculardır. Öncelikle kulüplerden izin alınarak futbolculara araştırmaya konu olan ölçek formları dağıtılmıştır. Dağıtılan ölçek formlarına iki hafta içerisinde yanıt vermeleri istenmiştir. Formlarının toplanmasında gizliliğe önem verilmiştir. Başlangıçta kulüplere dağıtılan toplam ölçek sayısı 125'tir. Daha sonra formların 104'ünün geri döndüğü tespit edilmiştir (ölçek formlarının geri dönüş oranı \%83,2). Yapılan incelemelerde hatalı görülen 2 form analizlere dahil edilmemiş, tam olarak doldurulan 102 ölçek formu analiz için uygun bulunmuştur.

\section{İstatistiksel Analiz}

Ölçeklerin güvenirliliği için Cronbach alpha katsayısı hesaplanmıştır. Ardından değişkenler arasındaki ilişkilerin yönünü ve kuvvetini belirlemek için korelasyon analizi, mobbingin tükenmiş̧lik boyutları üzerindeki etkisini tespit edebilmek için de çoklu regresyon analizi yapılmıştır. Futbolcuların mobbing davranışına maruz kalma ile tükenmişlik düzeylerinin belirlenmesinde aritmetik ortalama ve standart sapma değerleri kullanılmıştır. Her iki değişkene yönelik değerlendirmeler ise şu puan aralıklarına göre yapılmışıtır: 1,00-1,79 arası "hiçbir zaman"; 1,80-2,59 aras1 "nadiren"; 2,60-3,39 arası "ara sıra"; 3,40-4,19 aras1 "çoğu zaman"; 4,20-5,00 aras1 "her zaman". 


\section{BULGULAR}

\section{Demografik Özellikler}

Demografik özellikler incelendiğinde futbolcuların çoğunun bekâr $(\% 88,2)$ ve lise mezunu $(\% 54,9)$ olduğu görülmektedir. Futbolcuların \%64,7'si genellikle ilk 11'e girmekte, 30,4'ü genelde yedek kalmakta, $\% 4,9$ 'u ise genelde kadroda kendilerine yer bulamamaktadırlar. Futbolcuların yaş ortalamaları 23,3; şuan oynadığı kulüpte bulunma yılı 2,43; toplam futbol oynama yll ise 10,16'dır (Tablo 1).

Tablo 1. Futbolcuların demografik özellikleri

\begin{tabular}{lcc}
\hline Medeni Durum & f & \% \\
\hline Evli & 12 & 11.8 \\
Bekar & 90 & 88.2 \\
Toplam & 102 & 100 \\
\hline Eğitim Durumu & $\mathbf{f}$ & $\mathbf{\%}$ \\
\hline Lise & 56 & 54.9 \\
Üniversite & 46 & 45.1 \\
Toplam & 102 & 100 \\
\hline Takımdaki Pozisyon Durumu & $\mathbf{f}$ & $\mathbf{\%}$ \\
\hline Genelde ilk 11'e girerim & 66 & 64.7 \\
Genelde yedek kalırım & 31 & 30.4 \\
Genelde kadroda yer alamam & 5 & 4.9 \\
Toplam & 102 & 100 \\
\hline Diğer Değişkenler & $\mathbf{X}(\mathbf{y l})$ & $\mathbf{S S}$ \\
\hline Yaş & 23.3 & 4.52 \\
Şu an oynadı̆̆ kulüpte bulunma yılı & 2.43 & 1.70 \\
Toplam futbol oynama yılı & 10.16 & 3.71 \\
\hline
\end{tabular}

\section{Güvenirlik Analizi Sonuçları}

Çalışmada kullanılan Olumsuz Davranışlar Ölçeği-Futbol'un Cronbach alpha katsayısının 0,760 olduğu tespit edilmiş olup, bu sonuç ölçeğin "oldukça güvenilir" olduğunu göstermektedir (Alt boyutlar; kişi ilişkili mobbing $=0,757$, iş ilişkili mobbing $=0,705$, fiziksel korkutucu mobbing=0,684). Çalışmada kullanılan diğer ölçek olan Sporcu Tükenmişlik Ölçeğinin Cronbach alpha katsayısı ise 0,873 olduğu tespit edilmiştir. Bu sonuç ölçeğin "yüksek derecede güvenilir" olduğunu göstermektedir (Alt boyutlar; başarıda düşüş hissi=0,746, duygusal/fiziksel tükenme $=0,692$, duyarsızlaşma $=0,714)$ (Özdamar, 1999:522). 


\section{Korelasyon Analizi Sonuçları}

Korelasyon analizine göre, tükenmişliğin bağımsız değişkenler ile herhangi bir ilişkisi bulunmamaktadır. Diğer taraftan tükenmişliğin mobbing ve alt boyutları ile ilişkisi bulunmaktadır. Buna göre tükenmişliğin, mobbing $(r=0,411 ; P<0,01)$, kişi ilişkili mobbing $(r=0,312 ; P<0,01)$, iş ilişskili mobbing $(r=0,311 ; P<0,01)$ ve fiziksel korkutucu mobbing $(r=0,345 ; P<0,01)$ ile anlamlı ve pozitif ilişkisi söz konusudur. Tükenmişliğin bu değişkenlerle ilişkisinin “orta düzeyde" olduğu söylenebilir (Tablo 2).

Tablo 2. Korelasyon analizi

\begin{tabular}{|c|c|c|c|c|c|c|c|c|c|c|}
\hline Değişkenler & 1 & 2 & 3 & 4 & 5 & 6 & 7 & 8 & 9 & 10 \\
\hline 1. Yaş & 1 & & & & & & & & & \\
\hline 2. Şuanki kulüpte oynama yılı & -.043 & 1 & & & & & & & & \\
\hline 3. Toplam futbol oynama yılı & $.780^{* *}$ & .015 & 1 & & & & & & & \\
\hline 4. Kişi ilişkili mobbing & $-.273^{* *}$ & $-.208^{*}$ & -.159 & 1 & & & & & & \\
\hline 5. İş ilişkili mobbing & -.151 & -.110 & $-.255^{* *}$ & $.505^{* * *}$ & 1 & & & & & \\
\hline 6. Fiziksel korkutucu mobbing & $.288^{* *}$ & $-.251^{*}$ & $.203^{*}$ & $.292^{* *}$ & $.401^{* *}$ & 1 & & & & \\
\hline 7. Duygusal/fiziksel tükenme & .139 & .096 & .057 & $.229^{*}$ & $.229^{*}$ & $.225^{*}$ & 1 & & & \\
\hline 8. Duyarsızlaşma & .158 & .099 & -.033 & .125 & $.240^{*}$ & $.243^{*}$ & $.720^{* *}$ & 1 & & \\
\hline 9. Başarıda düşüş hissi & .101 & .019 & .082 & $.416^{* *}$ & $.321^{* *}$ & $.396^{* *}$ & $.670^{* *}$ & $.470^{* *}$ & 1 & \\
\hline 10. Mobbing & -.097 & $-.235^{*}$ & -.122 & $.802^{* *}$ & $.842^{* *}$ & $.672^{* *}$ & $.292^{* *}$ & $.255^{* *}$ & $.481^{* *}$ & 1 \\
\hline 11. Tükenmişlik & .151 & .078 & .044 & $.312^{* *}$ & $.311^{* *}$ & $.345^{* *}$ & $.908^{* *}$ & $.828^{* *}$ & $.853^{* *}$ & $.411^{* *}$ \\
\hline
\end{tabular}

\section{Futbolcuların Mobbing ve Tükenmişlik Düzeyleri}

Tablo 3'e göre, amatör futbolcuların mobbing davranışına maruz kalmalarının oldukça düşük olduğu görülmüştür. Mobbing boyutları içerisinde kişi ilişkili mobbing, iş ilişkili ve fiziksel mobbing davranışına göre daha yüksektir. Futbolcuların genel tükenmişlik düzeyleri de düşüktür. Futbolcular nadiren başarıda düşüş hissi yaşamaktadırlar. 
Tablo 3. Futbolcuların mobbing ve tükenmişlik düzeyleri

\begin{tabular}{llcc}
\hline Değişkenler & & X & SS \\
\hline Mobbing & Kişi ilişkili mobbing davranışına maruz kalma & 1.61 & .51 \\
& İş ilişkili mobbing davranışına maruz kalma & 1.44 & .51 \\
& Fiziksel korkutucu mobbing davranışına maruz kalma & 1.24 & .38 \\
& Genel mobbing davranışına maruz kalma & 1.43 & .36 \\
Tükenmişlik & Duygusal/fiziksel tükenme & 1.53 & .46 \\
& Duyarsızlaşma & 1.48 & .51 \\
& Başarıda düşüş hissi & 1.84 & .62 \\
& Genel tükenmişlik & 1.62 & .46 \\
\hline
\end{tabular}

\section{Çoklu Regresyon Analizi Sonuçları}

\section{Bağımsız Değişkenlerin Duygusal/Fiziksel Tükenme Üzerindeki Etkisine Yönelik Çoklu Regresyon Analizi}

Yapılan çoklu regresyon analiz sonucunda, bağımsız değişkenlerden sadece "şuanki kulüpte oynama yllı" $(\beta=0,202 ; \quad P<0,05)$ duygusal/fiziksel tükenmeyi anlamlı olarak etkilemektedir. Diğer taraftan, mobbingin alt boyutlarından sadece "kişi ilişkili mobbing" $(\beta=0,261 ; P<0,05)$ duygusal/fiziksel tükenmeyi anlamlı olarak etkilemektedir. "Kişi ilişkili mobbing" burada en fazla etkileyicilik gücüne sahiptir (Tablo 4).

Tablo 4. Bağımsız değişkenlerin duygusal/fiziksel tükenme üzerindeki etkisine yönelik çoklu regresyon analizi sonuçları

\begin{tabular}{lccccc}
\hline \multirow{2}{*}{ Bağımsız Değişkenler } & \multicolumn{2}{c}{$\begin{array}{c}\text { Standartlaştırılmamış } \\
\text { Katsayılar }\end{array}$} & $\begin{array}{c}\text { Standartlaştırılmış } \\
\text { Katsayılar }\end{array}$ & \multirow{2}{*}{$t$} & $P$ \\
\cline { 2 - 5 } & Beta & St.Hata & Beta & & \\
\hline Yaş & .033 & .017 & .323 & 1.946 & .055 \\
Şuanki kulüpte oynama yılı & .055 & .027 & .202 & 2.039 & .044 \\
Toplam futbol oynama yılı & -.019 & .020 & -.154 & -.967 & .336 \\
Kişi ilişkili mobbing & .239 & .110 & .261 & 2.175 & .032 \\
İşilişkili mobbing & .079 & .111 & .087 & .716 & .476 \\
Fiziksel korkutucu mobbing & .125 & .142 & .103 & .883 & .379 \\
\hline & $R^{2}=0,158 ;$ Düzeltilmiş $R^{2}=0,105 ; F=2,974 ; P<0,05$ \\
\hline
\end{tabular}




\section{Bağımsız, Değişkenlerin Duyarsızlaşma Üzerindeki Etkisine Yönelik Çoklu Regresyon Analizi}

Yapılan çoklu regresyon analiz sonucunda, bağımsız değişkenlerden "yaş" ( $\beta=0,489$; $P<0,01)$, "şuanki kulüpte oynama y1lı" $(\beta=0,205 ; P<0,05)$ ve "toplam futbol oynama y1lı" $(\beta=-$ 0,400; $P<0,05)$ duyarsızlaşmayı anlamlı olarak etkilemektedir. Diğer taraftan, mobbingin alt boyutlarından hiçbirinin duyarsızlaşmaya anlamlı etkisi yoktur. Bağımsız değişkenlerden "yaş” burada en fazla etkileyicilik gücüne sahiptir (Tablo 5).

Tablo 5. Bağımsız değişkenlerin duyarsızlaşma üzerindeki etkisine yönelik çoklu regresyon analizi sonuçları

\begin{tabular}{lccccc}
\hline \multirow{2}{*}{ Bağımsız Değişkenler } & \multicolumn{2}{c}{$\begin{array}{c}\text { Standartlaştırılmamış } \\
\text { Katsayılar }\end{array}$} & $\begin{array}{c}\text { Standartlaştırılmış } \\
\text { Katsayılar }\end{array}$ & \multirow{2}{*}{$t$} & \multirow{2}{*}{$P$} \\
\cline { 2 - 4 } & Beta & St.Hata & Beta & & \\
\hline Yaş & .056 & .019 & .489 & 3.010 & .003 \\
Şuanki kulüpte oynama yılı & .062 & .029 & .205 & 2.112 & .037 \\
Toplam futbol oynama yılı & -.056 & .022 & -.400 & -2.554 & .012 \\
Kişi ilişkili mobbing & .143 & .119 & .142 & 1.205 & .231 \\
İş ilişkili mobbing & .102 & .121 & .101 & .847 & .399 \\
Fiziksel korkutucu mobbing & .206 & .154 & .153 & 1.338 & .184 \\
\hline \multicolumn{7}{l}{} \\
\hline
\end{tabular}

${ }^{*} P<0,05 ;{ }^{* *} P<0,01$

\section{Bağımsız Değişkenlerin Başarıda Düşüuş Hissi Üzerindeki Etkisine Yönelik Çoklu Regresyon Analizi}

Yapılan çoklu regresyon analiz sonucunda, bağımsız değişkenlerden sadece "şuanki kulüpte oynama yılı” $(\beta=0,180 ; P<0,05)$ başarıda düşüş hissini anlamlı olarak etkilemektedir. Diğer taraftan, mobbingin alt boyutlarından "kişi ilişkili mobbing" $(\beta=0,392 ; P<0,01)$ ve "fiziksel korkutucu mobbing" $(\beta=0,261 ; P<0,05)$ başarıda düşüş hissini anlamlı olarak etkilemektedir. "Kişi ilişkili mobbing” burada en fazla etkileyicilik gücüne sahiptir (Tablo 6). 
Tablo 6. Bağımsız değişkenlerin başarıda düşüş hissi üzerindeki etkisine yönelik çoklu regresyon analizi sonuçları

\begin{tabular}{|c|c|c|c|c|c|}
\hline \multirow{2}{*}{ Bağımsız Değişkenler } & \multicolumn{2}{|c|}{$\begin{array}{l}\text { Standartlaştırılmamış } \\
\text { Katsayılar }\end{array}$} & \multirow{2}{*}{$\begin{array}{c}\begin{array}{c}\text { Standartlaştırılmış } \\
\text { Katsayılar }\end{array} \\
\text { Beta }\end{array}$} & \multirow[t]{2}{*}{$t$} & \multirow{2}{*}{$P$} \\
\hline & Beta & St.Hata & & & \\
\hline Yaş & .024 & .021 & .176. & 1.167 & .246 \\
\hline Şuanki kulüpte oynama yılı & .066 & .033 & .180 & 1.995 & .049 \\
\hline Toplam futbol oynama yılı & -.006 & .025 & -.034 & -.235 & .814 \\
\hline Kişi ilişkili mobbing & .482 & .134 & .392 & 3.593 & .001 \\
\hline İş ilişkili mobbing & .068 & .136 & .056 & .501 & .618 \\
\hline Fiziksel korkutucu mobbing & .426 & .173 & .261 & 2.459 & .016 \\
\hline
\end{tabular}

\section{Bağımsız Değişkenlerin Tükenmişlik Üzerindeki Etkisine Yönelik Çoklu Regresyon Analizi}

Yapılan çoklu regresyon analiz sonucunda, bağımsız değişkenlerden "yaş" $(\beta=0,371$; $P<0,05)$ ile "şuanki kulüpte oynama yllı" $(\beta=0,226 ; P<0,05)$ tükenmişliği anlamlı olarak etkilemektedir. "Yaş" burada en fazla etkileyicilik gücüne sahiptir. Diğer taraftan, mobbingin alt boyutlarından sadece "kişi ilişkili mobbing" $(\beta=0,318 ; P<0,01)$ tükenmişliği anlamlı olarak etkilemektedir (Tablo 7).

Tablo 7. Bağımsız değişkenlerin tükenmişlik üzerindeki etkisine yönelik çoklu regresyon analizi sonuçları

\begin{tabular}{lccccc}
\hline \multirow{2}{*}{ Bağımsız Değişkenler } & \multicolumn{2}{c}{$\begin{array}{c}\text { Standartlaştırılmamış } \\
\text { Katsayılar }\end{array}$} & $\begin{array}{c}\text { Standartlaştırılmış } \\
\text { Katsayılar }\end{array}$ & \multirow{2}{*}{$t$} & $P$ \\
\cline { 2 - 5 } & Beta & St.Hata & Beta & & \\
\hline Yaş & .038 & .016 & .371 & 2.392 & .019 \\
Şuanki kulüpte oynama yılı & .061 & .025 & .226 & 2.439 & .017 \\
Toplam futbol oynama yılı & -.027 & .019 & -.217 & -1.451 & .150 \\
Kişi ilişkili mobbing & .288 & .102 & .318 & 2.837 & .006 \\
İş ilişkili mobbing & .083 & .103 & .092 & .810 & .420 \\
Fiziksel korkutucu mobbing & .252 & .131 & .209 & 1.924 & .057 \\
\hline \multicolumn{2}{l}{} \\
\hline
\end{tabular}

${ }^{*} P<0,05 ;{ }^{* *} P<0,01$ 


\section{TARTIŞMA VE SONUÇ}

$\mathrm{Bu}$ çalışmanın sonucu, amatör futbolcuların mobbing algılarının ve tükenmişlik düzeylerinin oldukça düşük olduğunu göstermektedir. Buna karşın, profesyonel futbolculara yönelik olarak yapılan diğer araştırmalarda hem mobbing algılama (İyem, 2007) hem de tükenmişlik (Yıldız, 2011) düzeylerinin amatör sporculara göre yüksek olduğu görülmektedir. Bunun sebebi, profesyonel futbolun endüstri haline gelmesi, yüksek ödüllerin futbolcuları rekabete sokmasından kaynaklandığı söylenebilir.

Diğer taraftan bu çalışmanın diğer sonucu, amatör futbol takımlarındaki mobbing davranışlarının futbolcuların tükenmişliğini anlamlı olarak etkilediğini ortaya koymaktadır. Diğer bir deyişle, mobbing davranışları futbolcuların tükenmişliğini artırmaktadır. Korelasyon analizine göre mobbing ile tükenmişlik arasındaki ilişkinin kuvveti orta düzeydedir (Cohen, 1988). Bu sonuçlara göre bu çalışma, literatürde yer alan diğer araştırma sonuçları ile benzerlikler göstermektedir (Karık ve Yıldız, 2015).

Diğer sektörlerde yapılan araştırmalara göre, mobbing davranışları çalışanların tükenmişliğini pozitif etkilemektedir (Albar ve Ofluoğlu, 2017). Son yıllarda spor sektöründe yapılan araştırmalarda da benzer sonuçlar görülmüsşür. Türkiye Profesyonel Süper Liginde yapılan araştırmada, bazı futbolcuların takım arkadaşları ve yöneticiler tarafından mobbing davranışına maruz kaldıkları tespit edilmiştir (İyem, 2007). Profesyonel futbolcular üzerinde yapılan diğer bir araştırmada, mobbing davranışlarının futbolcuların tükenmişliğini anlamı ve pozitif etkilediği bulunmuştur (Yıldız, 2015). Yine futbolda, ancak antrenörler üzerinde yapılan başka bir araştırmada, antrenörler üzerinde negatif davranışlar tespit edilmiştir. Bu araştırma sonuçlarına göre, futbol kulüplerinde sportif beklentiler karşılanamadığı zaman, antrenörler kulüp menajerleri ve medyanın baskılarına maruz kalmakta, dolayısıyla bu durum antrenörleri negatif etkilemektedir. Ayrıca, negatif davranışlara daha çok genç antrenörler maruz kalmaktadır (Cengiz, Yenel ve Sunay, 2013). Mobbingin tükenmişliğe olan etkisi basketbol branşında da incelenmiştir. Türkiye Kadınlar Basketbol 1. Ligindeki basketbol takımlarında bulunan oyuncular üzerinde gerçekleştirilen araştırmada, mobbing davranışları kadın basketbolcuların tükenmişliğini anlamlı ve pozitif yönde etkilediği bulunmuştur (Karık ve Yıldız, 2015). Yukarıdaki araştırmalarda da görüleceği üzere, bu çalışma diğer araştırmalarla benzerlik göstermektedir. 
Bu çalışmada ayrıca, mobbingin alt boyutlarının tükenmişliğin alt boyutlarına olan etkileri ayrı ayrı incelenmiştir. Duygusal/fiziksel tükenmenin sadece "kişi ilişkili mobbing" ile bağımsız değişkenlerden sadece “şuanki kulüpte oynama yılı"ndan anlamlı olarak etkilendiği görülmüştür. Burada, kişi iliş̧ili mobbing davranışlarının futbolcuların duygusal/fiziksel tükenmesini artırdığı, ayrıca futbolcuların şuanki kulüpte oynama yılı arttıkça -mobbingden bağımsız olarakfutbolcuların duygusal/fiziksel tükenmesini artırdığı söylenebilir. Benzer şekilde, basketbol takımlarında bulunan oyuncular üzerinde gerçekleştirilen bir araştırmada, kişi ilişkili mobbing davranışlarının kadın basketbolcuların tükenmişliğini anlamlı ve pozitif yönde etkilediği bulunmuştur (Karık ve Yıldız, 2015). Duyarsızlaşma mobbingin alt boyutlarından hiçbirinden anlamlı olarak etkilenmezken, bağımsız değişkenlerden "yaş", "şuanki kulüpte oynama yılı" ve “toplam futbol oynama yılı"dan anlamlı olarak etkilendiği görülmüştür. Mobbingden bağımsız olarak, futbolcuların yaşı ilerledikçe ve futbol oynama yılı arttıkça çevrelerine karşı daha fazla duyarsızlaşmaktadır. $\mathrm{Bu}$ durumun uzun yıllar aynı işi yapmanın verdiği yorgunluktan kaynaklandığı söylenebilir. Başarıda düşüş hissi mobbingin alt boyutlarından sadece "kişi ilişsili mobbing" ve "fiziksel korkutucu mobbing"den anlamlı olarak etkilenmektedir. Kişi ilişkili mobbing ile fiziksel korkutucu mobbinge maruz kalan futbolcular başarılarında düşüş hissine kapıldıkları söylenebilir. Ayrıca, başarıda düşüş hissi bağımsız değişkenlerden sadece "şuanki kulüpte oynama yllı"ndan etkilenmektedir. Futbolcuların tükenmişliğine genel olarak bakıldığında, tükenmişliğin mobbingin alt boyutlarından sadece "kişi ilişkili mobbing"den; bağımsız değişkenlerden ise sadece "yaş" ile "şuanki kulüpte oynama yılı"ndan anlamlı olarak etkilendiği görülmüştür. Buna göre futbolcuların yaşları ve mevcut takımında bulunma süresi arttıkça tükenmişlikleri de artmaktadır. Bunun sebebi, yaşın ve oynama yılının artması ile birlikte futbolcuların fiziksel ve zihinsel olarak beklenen iş yükünü kaldırmakta zorlanmaları olabilir. Profesyonel futbolcular üzerinde yapılan bir araştırmada, mobbing davranışlarının futbolcuların tükenmişliğini tüm alt boyutlarda anlamı ve pozitif etkilediği bulunmuştur. Bununla birlikte, tükenmişliğin bağımsız değişkenlerden hiçbiri ile anlamlı bir ilişkisi görülmemiştir (Yıldız, 2015). Diğer araştırmaların sonuçları bu çalışma ile karşılaştırıldığında, farklılığın futbolcuların amatör ve profesyonel statüde olmalarından kaynaklandığı söylenebilir. Profesyonel futbolcuların mobbingten daha fazla etkilenmeleri, profesyonel futbolda para kazanmanın ön planda olmasından kaynaklandığı söylenebilir. 
Yıldız, B.S., Kepoğlu, A. ve Yıldız, S.M. (2018). Mobbing davranışlarının amatör futbolcuların tükenmişliğine etkisi. $C B \ddot{U}$ Beden Eğitimi ve Spor Bilimleri Dergisi, 13(2), 231-246.

Sonuç olarak bu çalışma, futbol takımlarında mobbing davranışlarının futbolcuların tükenmişliğini artıracağını ortaya koymaktadır. Futbol takımlarının sadece rakip takımlarla rekabeti söz konusu değildir, bunun yanında futbolcuların takım içerisinde aktif rol almak ve ön plana çıkmak istemeleri de takım içi rekabeti gündeme getirmektedir (Yıldız, 2015). Tükenmişliğin kişilerin performansını ciddi derecede düşürdüğü göz önüne alındığında, başarılı olmak isteyen futbol kulüplerinin yöneticileri ve antrenörleri takım içerisindeki mobbing davranışlarını önlemeleri ve bu tür davranış ortaya çıktığında engellemeleri gerekmektedir. Bunun için spor kulüplerinin tüm üyelerine yönelik mobbing farkındalığını yaratacak eğitimler verilmesi önerilebilir.

\section{KAYNAKLAR}

Albar, B.Ö. ve Ofluoğlu, G. (2017). Çalışma hayatında mobbing ve tükenmişlik ilişkisi. HAK-İŞ Uluslararası Emek ve Toplum Dergisi, 6(6), 538-550.

Amman, M.T. (2000). Spor sosyolojisi. İçinde Sporda Sosyal Bilimler, Ed: H.C. İkizler, İstanbul: Alfa Basım.

Arı, G.S. ve Bal, E.Ç. (2008). Tükenmişlik kavramı: Bireyler ve örgütler açısından önemi. Yönetim ve Ekonomi, Celal Bayar Üniversitesi İktisadi ve İdari Bilimler Fakültesi, 15(1), 132-148.

Biber, E., Ersoy, A., Acet, M. ve Küçük, V. (2010). Türk futbol antrenörlerinin tükenmişlik düzeylerinin değerlendirilmesi. Selçuk Üniversitesi Beden Eğitimi ve Spor Bilim Dergisi, 12(2), 134-143.

Cengiz, R., Yenel, I.F. ve Sunay, H. (2013). A research on mobbing behaviors football trainers face in club environment. Turkish Journal of Sport and Exercise, 15(1), 88-94.

Cohen, J. (1988). Statistical power analysis for the behavioral sciences. (2 $2^{\text {nd }}$ Edition). NJ: Lawrence Erlbaum.

Davenport, N., Schwartz, R.D. \& Elliot, G.P. (1999). Mobbing: Emotional abuse in the American workplace. Ames, IA: Civil Society Publishing.

Demerouti, E., Bakker, A., \& Leiter, M. (2014). Burnout and job performance: The moderating role of selection, optimization, and compensation strategies. Journal of Occupational Health Psychology, 19(1), 96-107.

Devonish, D. (2013). Workplace bullying, employee performance and behaviors: The mediating role of psychological wellbeing. Employee Relations, 35(6), 630-647.

Einarsen, S., Hoel, H., \& Notelaers, G. (2009). Measuring exposure to bullying and harassment at work: validity, factor structure and psychometric properties of the Negative Acts Questionnaire-Revised. Work \& Stress, 23(1), 24-44.

Ekici, S. (2011). Burnout levels of sport managers in provincial organizations of Turkish Youth and Sport General Directorate. African Journal of Business Management, 5(15), 7162-7164.

Freudenberger, H.J. (1974). Staff burn-out. Journal of Social Issues, 30(1), 159-165.

İyem, C. (2007). Futbolda mobbing: Sakaryaspor A.Ş. örneği. XV. Ulusal Yönetim ve Organizasyon Kongresi Bildiriler Kitab1, Sakarya, 919-938.

Karasar, N. (2005). Bilimsel Araştırma Yöntemleri. 15. Baskı, Ankara: Nobel Yayınevi.

Karık, T. ve Yıldız, S.M. (2015). Mobbing davranışlarının kadın basketbolcuların tükenmişliği üzerine etkisi. Uluslararası İnsan Bilimleri Dergisi, 12(2), 430-442.

Kelecek, S., Kara, F.M., Çetinkalp, Z.K. ve Aşçı, H. (2016). Sporcu tükenmişlik ölçeği'nin Türkçe uyarlaması. Spor Bilimleri Dergisi, 27(4), 149-161.

Kelecek, S. ve Göktürk, E. (2017). Kadın futbolcularda sporcu bağlılığının sporcu tükenmişliğini belirlemedeki rolü. Başkent Üniversitesi Sağlık Bilimleri Fakültesi Dergisi, 2(2), 162-173.

Leymann, H. (1996). The content and development of mobbing at work. European Journal of Work and Organizational Psychology, 5(2), 165-184.

Maslach, C., \& Jackson, S.E. (1981). The measurement of experienced burnout. Journal of Occupational Behavior, 2, 99-113.

Maslach, C. (2003). Job burnout: New directions in research and intervention. Current Directions in Psychological Science, 12(5), 189-192.

Neuman, J.H., \& Keashly, L. (2004). Development of the Workplace Aggression Research Questionnaire (WAR-Q): Preliminary data from the workplace stress and aggression project. Paper presented at the annual meeting of the Society of Industrial and Organizational Psychology, Chicago.

Ok, S. (2012). Banka çalışanlarının tükenmişlik düzeylerinin iş doyumu, rol çatışması, rol belirsizliği ve bazı bireysel özelliklere göre incelenmesi. Türk Psikolojik Danışma ve Rehberlik Dergisi, 3(21), 57-67. 
Yıldız, B.S., Kepoğlu, A. ve Yıldız, S.M. (2018). Mobbing davranışlarının amatör futbolcuların tükenmişliğine etkisi. $C B \ddot{U}$ Beden Eğitimi ve Spor Bilimleri Dergisi, 13(2), 231-246.

Özdamar, K. (1999). Paket programlar ile istatistiksel veri analizi. Eskişehir: Kaan Kitapevi.

Raedeke, T.D., \& Smith, A.L. (2001). Development and preliminary validation of an athlete burnout measure. Journal of Sport and Exercise Psychology, 23, 281-306.

Salman, M.N., ve Yalçındağ, S. (2017). Sporda mobbing uygulamaları ve sporcuların mobbing algılama düzeylerinin tespiti. Kastamonu Ĕ̌gitim Dergisi, 25(6), 2479-2490.

Tetik, S. (2010). Mobbing kavramı: Birey ve örgütler açısından önemi. KMÜ Sosyal ve Ekonomik Araştırmalar Dergisi, 12(18), 81-89.

Tınaz, P. (2006). İşyerinde psikolojik taciz (mobbing). Çalışma ve Toplum, 4, 13-28.

Tutar, H. (2015). Mobbing. Nedenleri ve başa çıkma stratejileri: Kuramsal yaklaşım. Ankara: Nobel Yayınevi.

Yildız, S.M. (2011). Relationship between leader-member exchange and burnout in Professional footballers. Journal of Sport Sciences, 29(14), 1493-1502.

Yıldız, S.M. (2015). The Relationship between bullying and burnout: An empirical investigation of Turkish professional football players. Sport, Business and Management: An International Journal, 5(1), 6-20.

Yıldız, S.M. (2017). Örgütsel davranış Seçme konular. Ankara: Detay Yayıncılık. 